Volume 9, No.1.3, 2020

International Journal of Advanced Trends in Computer Science and Engineering

Available Online at http://www.warse.org/IJATCSE/static/pdf/file/ijatcse2491.32020.pdf

https://doi.org/10.30534/ijatcse/2020/2491.32020

\title{
CHECKDYSC@: Mobile Game for Early Detection of Dyscalculia Signs in Children
}

\author{
Mazeyanti Mohd Ariffin ${ }^{1}$, Nurshazlyn Mohd Aszemi ${ }^{1}$, Nurdiyanah Ismir ${ }^{2}$ \\ ${ }^{1}$ Universiti Teknologi PETRONAS, Malaysia, mazeyanti@utp.edu.my \\ ${ }^{2}$ International Business Machine (IBM), Malaysia
}

\begin{abstract}
CheckDysc is a mobile game which was constructed to diagnose children with Dyscalculia. Dyscalculia refers to learning difficulty which related to mathematics. Commonly, children who struggling with mathematics were categorized as low achievers however most of parents and also pre-school teachers are not aware that these low achiever students could be Dyscalculia. Hence, the aim of CheckDysc is to provide early detection of Dyscalculia signs and alert the parents and pre-school teachers. The CheckDysc was constructed based on feedbacks and guidance from the learning disability experts and teachers. CheckDysc was evaluated in terms of its usability and effectiveness to assess the Dyscalculia signs in children.
\end{abstract}

Key words: Dyscalculia, Early-Detection, Learning Disability, Mathematics.

\section{INTRODUCTION}

Learning Disability (LD) refers to problem which related to the brain capacity to receive, process, analyse and store information [1]. Normally, people who were diagnosed as LD have issues with fundamental learning activities such as reading, writing and counting. Dyslexia, Dysgraphia and Dyscalculia are some of LDs.

There are 29810 primary school children were diagnosed as LD and attended special education schools in Malaysia [2]. In Malaysia, Dyscalculia were treated and received the same treatments as Dyslexia although both faced very dissimilar learning difficulties. This is due to not many parents and even teachers know about Dyscalculia. Hence, this paper aims to introduce a mobile game called CheckDysc for screening Dyscalculia signs among children at the age of 4 till 5 years old, therefore early intervention could be given to these special children.

\section{METHODOLOGY}

\section{A. Learning Disabilities (LD) Dyscalculia}

Children with learning disability has processing problem with learning important aptitudes such as reading, writing and counting. Typically, they were always categorized as not interested to study but in actual the way they learn is different from normal children. There are several types of learning disabilities known as Dyslexia where these children have learning disability in reading, Dysgraphia where they have difficulties in writing and Dyscalculia for children with difficulty in mathematics. Malaysian Social Welfare Department declare learning disabilities in Malaysia are Dyslexia, Dyscalculia and Dysgraphia.

\section{B. Dyscalculia}

Dyscalculia is known as learning disability that has been characterized as the difficulty in basic arithmetic skills which are addition, subtraction, multiplication and division where it can occur to people across whole IQrange. Accordingto [3], considering people who perform poorly in mathematics have Dyscalculia is wrong since they are also people with specific numerical disorder. There are about 6 to 7 among 100 people that have Dyscalculia adding with those who are undiagnosed. These people will be facing problems of showing disinterest because whenever they are learning mathematics, they have issues in understanding the statement, decide which arithmetic operation should apply or even to make decision which can give enormous impact to them. Therefore, they might have started to develop a mathematics phobia.

Dyscalculia can be recognized earlier since the children started preschool. Different signs can be seen for children with Dyscalculia at different age and the sign will be more visible once the children getting older [4]. According to [5], the difficulties in calculating the object quantity, counting numbers, symbols used for numerical and the way they understand visual with numeric can be detected in the early age. Table 1 shows the early signs of Dyscalculia for children in the preschool age that has been listed [5]. 
Table 1: Early Signs of Dyscalculia

\begin{tabular}{|l|l|}
\hline No. & \multicolumn{1}{|c|}{ Early Signs of Dyscalculia } \\
\hline 1 & $\begin{array}{l}\text { Difficulties in connecting number concept to the } \\
\text { quantitative and symbolic form. }\end{array}$ \\
\hline 2 & $\begin{array}{l}\text { Difficulties in perceiving and representing shape as a } \\
\text { whole. }\end{array}$ \\
\hline 3 & $\begin{array}{l}\text { Difficulties in learning and recognizing number } \\
\text { symbols and conceiving the value of numbers when } \\
\text { referring to real life } \\
\text { subject. }\end{array}$ \\
\hline 4 & $\begin{array}{l}\text { Difficulties in recognizing the link between quantities } \\
\text { and set of arithmetic actions }\end{array}$ \\
\hline 5 & $\begin{array}{l}\text { Difficulties in counting number bigger than ten and } \\
\text { counting it down. }\end{array}$ \\
\hline 6 & $\begin{array}{l}\text { Face difficulties in discriminating which number is } \\
\text { larger or smaller }\end{array}$ \\
\hline 7 & Not familiar with basic number name. \\
\hline 8 & Difficulties in space organization \\
\hline
\end{tabular}

\section{Mobile Game}

Nowadays, numerous mobile games and applications has been developed to help children with learning disability which has contributed a lot in their learning progress. However, the development of games or application that can be used to diagnosed children with learning disabilities focusing on Dyscalculia is still scarce. As to date, there are three applications that has been developed to diagnose and analyses children with Dyscalculia which are Dyscalculium [6], Dyscalculia Screener [7] and online analysis system [8]. Table 2 shows the list of identified applications.

Table 2 List of Applications to Diagnose Dyscalculia [3]

\begin{tabular}{|c|c|}
\hline Application & Functions \\
\hline Dyscalculium & $\begin{array}{l}\text { Provides an individual profile for the } \\
\text { student with } 11 \text { subcategories, indicating } \\
\text { which parts he has weakness and an } \\
\text { overall score which determine if the } \\
\text { student is at risk of Dyscalculia or not. }\end{array}$ \\
\hline $\begin{array}{l}\text { Dyscalculia } \\
\text { Screener }\end{array}$ & $\begin{array}{l}\text { A quick and dependable tool of } \\
\text { identifying Dyscalculia. This tool runs on } \\
\text { a PC and uses keyboard responses. The } \\
\text { tests include counting dots and numerical } \\
\text { order which comprises of dot } \\
\text { enumeration, number comparison and } \\
\text { arithmetic achievement. }\end{array}$ \\
\hline $\begin{array}{l}\text { Online Analysis } \\
\text { System }\end{array}$ & $\begin{array}{l}\text { Automatically assess students, based on } \\
\text { their responses in mathematics questions. } \\
\text { The phases involve are matching, } \\
\text { numerical evaluation and analysis. }\end{array}$ \\
\hline
\end{tabular}

\section{METHODOLOGY}

Based on the literature, there are several problems that has been faced by these children. Children with Dyscalculia at the age of four to five years old are having problems with difficulties in learning how to count, unable to recognize the numbers that has been printed, has trouble in getting the idea of associating a number with the real amount of the objects exists, has problem in memorizing the numbers and has difficulties in organizing things in a logical way. Once the problem has been recognized, the features of CheckDysc are analysed. These features were also based on "Mathematics for Dyslexics and Dyscalculics" by Richard Ashcroft and Steve Chinn [9]. Later, these features are shown to the LD experts for their feedbacks.

Table 3 Methodology Activities

\begin{tabular}{|c|c|c|}
\hline Phases & Activities & $\begin{array}{c}\text { Outcome/ } \\
\text { Output }\end{array}$ \\
\hline Planning & $\begin{array}{c}\text { Produce project plan, } \\
\text { plan project timeline } \\
\text { and milestones. }\end{array}$ & $\begin{array}{c}\text { Overall project } \\
\text { plan with } \\
\text { estimated } \\
\text { timeline. }\end{array}$ \\
\hline \multirow{5}{*}{ Analysis } & $\begin{array}{c}\text { Gather requirements, } \\
\text { interview } \\
\text { Dyscalculia } \\
\text { specialist, analyze } \\
\text { and the characteristic } \\
\text { of Dyscalculia and } \\
\text { existing application. }\end{array}$ & $\begin{array}{c}\text { List of } \\
\text { Dyscalculia } \\
\text { children behavior, } \\
\text { early signs of } \\
\text { Dyscalculia and } \\
\text { existing } \\
\text { application. }\end{array}$ \\
\hline \multirow{5}{*}{ Implementation } & $\begin{array}{c}\text { Sketch user interface, } \\
\text { design storyboard }\end{array}$ & $\begin{array}{c}\text { User interface } \\
\text { storyboard design } \\
\text { according to the } \\
\text { children behavior }\end{array}$ \\
\hline & $\begin{array}{c}\text { Develop the mobile } \\
\text { game using unity. }\end{array}$ & $\begin{array}{c}\text { Create } 28 \text { different } \\
\text { scenes for the } \\
\text { whole game with } \\
\text { related } \\
\text { functions. }\end{array}$ \\
\hline \multirow{7}{*}{ Testing } & $\begin{array}{c}\text { Test the game } \\
\text { functionality on } \\
\text { normal children, } \\
\text { Dyscalculia children } \\
\text { and specialist. }\end{array}$ & $\begin{array}{c}\text { Usability testing } \\
\text { result and } \\
\text { effectiveness } \\
\text { testing result }\end{array}$ \\
\hline & & \\
\hline
\end{tabular}

\section{RESULTS AND DISCUSSION}

CheckDysc (figure 1) consists of three different topics to be tested which are counting numbers, arranging numbers and odd and even numbers. Every topic has 10 different questions that need to be answered by the user. At the end of every topic that the user answer will have the summarized mark for all the questions that they answer. Once they have finished answering all the question on every topic, the overall mark will be displayed, and the result of diagnosis will be given. If the user didn't manage to answer all the question correctly and didn't achieve the percentage that has been set, they may be at risk of having Dyscalculia. 


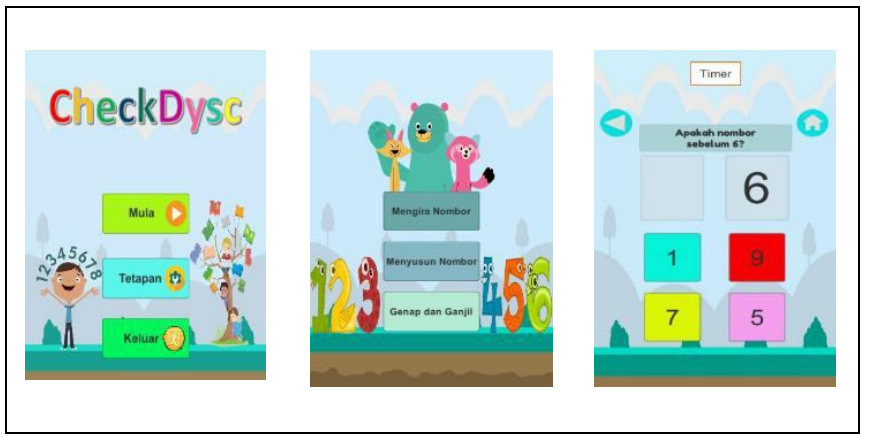

Figure 1: Checkdysc Game Interface

If they didn't achieve the percentage that has been set, a message will appear to indicate that they are at risk and need to have a proper check up with a specialist. Otherwise, if they are able to pass the percentage, they will receive a message stating that they are good and not at risk of having Dyscalculia. All the question will be set by referring to the book that has been written by Steve Chinn and Richard Ashcroft which titled Mathematics for Dyslexics and Dyscalculics [9].

In order to ensure the accurateness of the question, a testing with Dyscalculia children will be made to know whether it is suitable to be used for the application or not and their mark will be used for the diagnostic percentage. The diagnostic result will be following all the marks obtain from question that has been tested with Dyscalculia children. The user might be at risk of having Dyscalculia if they score $30 \%$ and below on the overall testing result while user that score $30 \%$ and above, they are free from Dyscalculic symptom or problem[10].

User that are diagnosed with Dyscalculia should have a proper check-up with specialist to get the right result on the problem that they faced.

Based on the literature search and feedbacks from the experts, CheckDysc was developed. CheckDysc was developed to help parents and teachers to conduct early-screening to their children for the possibility of having Dyscalculia. CheckDysc was constructed to replicate the mathematic level of four to five years old children.

\section{CONCLUSION}

As a conclusion, a mobile game called CheckDysc was successfully developed. Based on current research, there were very limited application that assist parents and teachers to detect Dyscalculia signs among children. Hence, the aim of CheckDysc was to provide early detection of Dyscalculia signs for parents and pre-school teachers.

From CheckDysc intervention, parents and teachers will be alerted and take appropriate measure in ensuring that their children get the right education and reduce the severity of the learning disability and ensure that their children able to learn like other normal children. The idea of utilizing game is to attract children in answering the questions interactively without having any sense of low interest when answering all the questions provided. Furthermore, children will be interested in playing the games since there will be features that can attract their attention when playing the game.

Additionally, CheckDysc could be leveraged as a platform to create awareness on Dyscalculia in Malaysia. Spreading the news will help parents to be aware of the learning disability and able to help their children in the learning process. There are many features that can be added to Dyscalculia in future such as able to diagnose the children learning disabilities in detail which has the summary of the current problem that they face, the topics that they have problem with and provide parents with a list of Dyscalculia specialist in Malaysia for further inspection. Furthermore, CheckDysc can add module where it can be used to teach children with Dyscalculia in learning mathematic and monitor their performances to sustain and increase their learning performance

In this study, a quadrotor UAV integrated with camera have been developed and tested in order to provide real time aerial video for traffic and emergency management. Through this study, the quadrotor can provide suitable information for ground staff to determine level of congestion and at the same time can monitor traffic violation by driver. This situation can be used when incident or accident happened which is can prevent road users used emergency land since this platform can send real time condition so that the authorities can take immediate action.

\section{ACKNOWLEDGEMENT}

This research is fully supported by ERGS grant, 203/PAERO/6730118. The authors fully acknowledged Ministry of Higher Education (MOHE) and Universiti Sains Malaysia for the approved fund which makes this important research viable and effective.

\section{REFERENCES}

1. F. Ferraz and J. Neves, "A Brief Look Into Dyscalculia And Supportive Tools," in The 5th IEEE International Conference on E-Health and Bioengineering - EHB 2015, 2015. https://doi.org/10.1109/EHB.2015.7391584

2. Ministry of Education Malaysia, "Quick Facts 2017 Malaysia Educational Statistics," 2017.

3. A. Drigas, M. . Pappas, and M. Lytras, "Emerging Technologies for ICT based Education for Dyscalculia: Implications for Computer Engineering Education.," Int. J. Eng. Educ., vol. 32, no. 4, pp. 1604-1610, 2016.

4. A. Morin, "Skills Affected by Dyscalculia | Math Learning Disability in Children," 2014. [Online]. Available:

https://www.understood.org/en/learning-attention-issues/ child-learning-disabilities/dyscalculia/skills-that-can-beaffected-by-dyscalculia. [Accessed: 29-May-2019]. 
5. A. Plerou, "Dealing With Dyscalculia Over Time," Icicte, no. 2008, pp. 1-12, 2014.

6. N. Beacham and C. Trott, "Screening for Dyscalculia within HE," MSOR Connect., vol. 5, no. 1, Apr. 2013. https://doi.org/10.11120/msor.2005.05010004

7. B. Butterworth, "Dyscalculia Screener," pp. 1-74, 2003.

8. N. L. Livne, O. E. Livne, and C. A. Wight, "Can Automated Scoring Surpass Hand Grading of Students' Constructed Responses and Error Patterns in Mathematics?" 2007.

9. S. J. Chinn and R. E. Ashcroft, Mathematics for dyslexics and dyscalculics : a teaching handbook.

10. Endah Sudarmilah, Iis Hamsir Ayub Wahab, Devi Afriyantari Puspa Putri, Wiwien Dinar Pratisti, Irma Yuliana. Game Education of Disaster Mitigation: A Systematic Literature Review. International Journal of Advanced Trends in Computer Science and Engineering, 8(6), November - December 2019, 2940- 2943

https://doi.org/10.30534/ijatcse/2019/42862019 